\title{
MOBILE PHONE DEPENDENCY AMONG HIGH SCHOOL STUDENTS IN RURAL AREA, CENTRAL JAVA
}

\author{
Ratih Dewi Yudhani ${ }^{1)}$, Dwi Rahayu ${ }^{2)}$, \\ Ratna Kusumawati3), Kusmadewi Eka D4) \\ 1)Department of Pharmacology, Faculty of Medicine, \\ Sebelas Maret University \\ 2)Department of Medical Education, Faculty of Medicine, \\ Sebelas Maret University \\ 3)Department of Psychology, Faculty of Medicine, \\ Sebelas Maret University \\ 4)Department of Nutrition, Faculty of Medicine, \\ Sebelas Maret University
}

\begin{abstract}
BACKGROUND : Studies have shown that frequent use of mobile phone, either smartphone or non-smartphone, may cause at least 16 inadvertent health-related effects: serious addiction, painful withdrawal, back problems, nerve damage, anxiety and depression, stress, weight problem and fitness level, disrupted sleep, source of bacteria, attention span, social effect, text claw, indirect injuries, eyesight, hearing, and radiation. This study aimed to compare level of dependency between use of smartphone and non-smartphone, as indicator by duration of use.

SUBJECTS AND METHOD: This was a cross sectional study conducted in Sukoharjo, Central Java. A sample of 219 high school students from a rural area, Sukoharjo, Central Java, was selected for this study. The dependent variable was duration use of smartphone or non-smartphone, as an indicator of dependency. The independent variable was type of mobile phone, i.e. smartphone or non-smartphone. A questionnaire was used to collect data. The data were analyzed using Mann-Whitney test.

RESULTS: Mean duration use of smartphone (mean $=5.50 ; \mathrm{SD}=1.10$ ) was longer than non-smartphone (mean=4.39; $\mathrm{SD}=0.90)$, and it was statistically significant $(\mathrm{p}=0.038)$.

CONCLUSION: The dependency is stronger among the smartphone users than non-smartphone users among high school students, as it is indicated by the longer duration of use.
\end{abstract}

Keywords: mobile phone, smartphone, side effect, dependency, rural, high school students 